\title{
PROSPECTS OF DEFINED PROTEINS FOR VACCINE DEVELOPMENT
}

\author{
ALBERTO C. C. FRASCH; DANIEL O. SANCHEZ \& JUAN J. CAZZULO
}

Instituto de Investigaciones Bioquímicas Fundación Campomar, Antonio Machado 151, 1405
Buenos Aires, Argentina

Parasitic diseases are major health problems in developing countries. Among them, Chagas disease, caused by the protozoan flagellate Trypanosoma cruzi, is prevalent in Central and South America. Even though the parasite and the disease were described more than 80 years ago, main problems like the mechanisms of pathogenesis, diagnosis and treatment, are still unsolved.

After an acute period with parasitemia, parasite growth is controlled by the host immune response. During this early phase of the infection, an important immunosupression takes place (see Petry \& Eisen, 1989 for a review). However, it is clear that several specific antibodies are produced (Reyes et al., 1990) and it has been suggested that this early humoral response is involved in the control of parasite growth which leads to the sharp decrease in parasitemia (Scott; 1981; Trischmann, 1984). The infection remains quiescent for many years. During the chronic phase, parasites are hardly detectable in the blood of patients who may develop progressive cardiac and/or gastrointestinal lesions. The mechanisms behind the development of these lesions are still controversial. It has been postulated that chronic Chagas disease involves an autoimmune process, which is still under discussion (see reviews in Hudson, 1985; Kierszenbaum, 1985; 1986). Since parasite growth is controlled during the acute period, and given the fact that only $20.30 \%$ of the infected persons develop symptoms years after the infection, host immune system should play an essential role in protection. Can this immune response be exploited to produce effective vaccines against the parasite?

\footnotetext{
The work in our laboratory was supported by grants from the UNDP-World Bank-WHO Special Programme for Research and Training in Tropical Diseases (TDR), Swedish Agency for Research Cooperation with Developing Countries (SAREC) and Programa Regional de Biotecnologia PNUD-UNESCO-ONUDI. ACCF, DOS and JJC are members of the Research Career from the National Research Council, Argentina.
}

The available information suggests that chemotherapeutic treatment with nifurtimox or benznidazole might completely eliminate the parasite if applied early after the infection. A prophylactic vaccine might do the same but without the undesirable side effects. Treatment of chronic infections, on the other hand, seem not to be successful. At present, it is not possible to estimate whether elimination of parasites in chronic patients may effectively prevent development of the disease. In this context, more basic information on the immunopathological process is needed. Even though its real effectiveness is unpredictable, development of a curative vaccine that might result in a milder chronic disease as a consequence of a lower load of parasites during the acute and chronic phases of the infection seems worth trying. A number of contributions from several laboratories suggest that is possible the immunological control of the parasitemia and death caused by $T$. cruzi experimental models. Firstly, a substantial decrease in parasitemia and death by passive transfer of sera or cells from infected or immunized animals has been reported (Burgess \& Hanson, 1979; Scott, 1981 ; Krettli, 1984; Trischmann, 1984; LimaMartins et al., 1985), and secondly, similar results might be obtained with animals immunized with dead or attenuated parasites and with parasite fractions, like flagella (Okanla et al., 1982; Villalta \& Kierszenbaum, 1983; Zweerink et al., 1984; Ritter \& Rowland, 1984; Ruiz et al., 1985; Andrews et al., 1985; Nickell \& Boyer, 1986; Basombrio \& Arredes, 1987). The protection obtained in most cases is partial, but this does not mean that it can not be improved if better antigens, adjuvants or immunization protocols are used. The possible existence of an autoimmune process in Chagas disease precludes, however, the utilization of complex or unidentified mixtures of antigens as components of a putative vaccine. In this context, there are also indications that purified antigens or antibodies against defined antigens might also protect against the infection (Scott \& Sna- 
TABLE

\begin{tabular}{|c|c|c|c|c|}
\hline Name & Reference & Protein $(\mathrm{kDa})^{\mathrm{a}}$ & Repeat (aa) & Remarks \\
\hline Tcg-1 & Peterson et al., 1986 & 85 & 9 & \\
\hline $\begin{array}{l}\text { pEC5 } \\
\text { FG1 }\end{array}$ & Dragon et al., 1987 & 85 & none & $\begin{array}{l}\text { heat-shock } \\
\text { protein }\end{array}$ \\
\hline hsp 70 & $\begin{array}{l}\text { Requena et al., } 1988 \\
\text { Engman et al., } 1989\end{array}$ & & 4 & $\begin{array}{l}\text { heat-shock } \\
\text { protein }\end{array}$ \\
\hline $\begin{array}{l}\text { antigen-1 } \\
\text { FRA } \\
\text { JL7 }\end{array}$ & $\begin{array}{l}\text { Ibañez et al., } 1988 \\
\text { Lafaille et al , } 1989 \\
\text { Levin et al., } 1989\end{array}$ & $\begin{array}{l}305 \\
300\end{array}$ & 68 & $\begin{array}{l}\text { detection of } \\
\text { chronic } \\
\text { infections }\end{array}$ \\
\hline $\begin{array}{l}\text { antigen-2 } \\
\text { TCR39 }\end{array}$ & $\begin{array}{l}\text { Ibañez et al., } 1988 \\
\text { Hoft et al., } 1989\end{array}$ & $\begin{array}{l}85 \\
82\end{array}$ & 12 & $\begin{array}{l}\text { detection of } \\
\text { chronic } \\
\text { infections }\end{array}$ \\
\hline antigen-10 & Ibañez et al., 1988 & $125 \cdot 150$ & 8 & \\
\hline antigen-13 & Ibañez et al., 1988 & 85 & 5 & \\
\hline antigen-15 & Ibañez et al., 1988 & $>205$ & 14 & \\
\hline $\begin{array}{l}\text { antigen }-30 \\
\text { CRA } \\
\text { JL8 } \\
\text { TCR27 }\end{array}$ & $\begin{array}{l}\text { Ibañez et al., } 1988 \\
\text { Lafaille et al., } 1989 \\
\text { Levin et al., } 1989 \\
\text { Hoft et al., } 1989\end{array}$ & $\begin{aligned} & 160-205 \\
& 225 \\
&> 170 \\
& \mathrm{ND}\end{aligned}$ & 14 & $\begin{array}{l}\text { detection of } \\
\text { chronic } \\
\text { infections }\end{array}$ \\
\hline $\begin{array}{l}\text { antigen }-36 \\
y_{L} 9\end{array}$ & $\begin{array}{l}\text { lbañez et al., } 1988 \\
\text { Levin et al., } 1989\end{array}$ & $\begin{array}{l}85 \\
40\end{array}$ & 38 & $\begin{array}{l}\text { Repeat similar } \\
\text { to a T. bruœi } \\
\text { MAPb }\end{array}$ \\
\hline antigen-54 & Ibañez et al., 1988 & 90 & none & \\
\hline SAPA & Affranchino et al., 1989 & $165-205$ & 12 & $\begin{array}{l}\text { detection of } \\
\text { early } \\
\text { infections }\end{array}$ \\
\hline TCR1 & Hoft et al., 1989 & ND & 34 & \\
\hline TCR3 & Hoft et al., 1989 & $180-250$ & 14 & $\begin{array}{l}\text { partially } \\
\text { homologous } \\
\text { to antigen-30 } \\
\text { CRA, JL8, } \\
\text { TCR27 }\end{array}$ \\
\hline TCR61 & Hoft et al., 1989 & ND & 6 & \\
\hline $\begin{array}{l}\text { TCR69 } \\
\text { TCR70 }\end{array}$ & Hoft et al., 1989 & ND & 7 & \\
\hline TCR101 & Hoft et al., 1989 & ND & 29 & \\
\hline JL1 & Levin et al., 1989 & 25 & none & \\
\hline JL5 & Levin et al., 1989 & 38 & none & $\begin{array}{l}\text { detection of } \\
\text { heart } \\
\text { disease }\end{array}$ \\
\hline pTt 34 & Takle et al., 1989 & 85 & none & \\
\hline A13 & Paranhos et al., 1990 & 230 & none & $\begin{array}{l}\text { detection of } \\
\text { acute and } \\
\text { chronic } \\
\text { infections }\end{array}$ \\
\hline
\end{tabular}

ND not determined.

a: The size of homologous proteins may differ among parasite isolates (see Wrightsman et al., 1986; Macina et al., 1989).

b: MAP microtubule-associated protein (see Schneider et al., 1988).

c: See Reyes et al., 1990. 
ry 1979 ; Snary 1983 ; Scott et al., 1984; 1985; Yoshida et al., 1989; Ouaissi et al., 1990; Ruiz et al., 1990). Furthermore, T. cruzi antigens involved in the generation of lytic antibodies (Krettli \& Brener 1982; Brener 1986; Mortara et al., 1988; Norris et al., 1989) or related to parasite penetration into host cells (Zingales et al., 1982; De Arruda, et al., 1989), have been described. These and other antigens might be potential components of a vaccine based on several molecules, provided that harmful side effects like an autoimmune response are ruled out.

Given the above considerations, it is essential to further define antigenic molecules from the parasite. Since most of these molecules are present in minute amounts in $T$. cruzi their direct purification from parasite extracts in amounts suitable for vaccine development is not feasible. Therefore, their obtention by recombinant DNA procedures seems to be at present a valid alternative. There is a rather large list of cloned genes for $T$. cruzi antigens available. Those from which at least a partial sequence was reported, are included in the Table. Even though it might not be complete, it is clear from this list that there are now several defined antigens that can be tested for their protective capacity against the infection. Most of these genes enconding parasite antigens were cloned and characterized through screening of expression DNA libraries with sera from infected humans or animals (Dragón et al., 1987; Ibañez et al., 1987). Several of them contain tandemly repeated sequences in their coding regions. The deduced length of the amino acid repeat unit is given in the Table. One conclusion from this table is that there are some antibodies that appear in high titers during infections since the corresponding antigens were identified by several groups. This is specially true for those proteins named antigen-30/CRA/JL8/TCR27 and antigen-1/ FRA/JL7. Consequently, it is likely that these defined antigens will also provide with new tools to improve the immunodiagnostic reagents used at present.

In the following sections, we will briefly describe our attempts to identify antigens that might be candidates as components of a putative vaccine against $T$. cruzi. Most of these experiments were performed using a panel of antigens identified in a $T$. cruz $i$ expression library with the aid of serum from a human infection (Ibañez et al., 1987). The partial DNA sequence, the proteins and RNAs encoded by them and their presence in different parasite stages, were previously reported (Ibañez et al., 1987; 1988; Affranchino et al., 1989; Souto. Padrón et al., 1989).

Presence of antigens and their genes in different parasite isolates - We have undertaken a series of experiments to assess whether the antigens and their genes are present in isolates from different geographical regions. Taking into account the diversity of $T$. cruzi due to its clonal origin (Tibayrenc \& Ayala, 1987), it is important to make sure that target antigens are present in most or all strains.

Recombinant antigens expressed in Escherichia coli systems were used to detect antibodies in sera from human infections (in collaboration with A. Luquetti and A. Rassi, University of Goiás; M. Camargo, University of Sāo Paulo; Myriam Lorca, University of Chile and L. Aslund and U. Petterson, University of Uppsala). One of them, named SAPA for shed acute phase antigen, and to a lesser extent antigens 13 and 36, detected antibodies mainly in acute and congenital infections (Affranchino et al., 1989; Reyes et al., 1990). Others, like those numbered 1,2 and 30 , detected antibodies mainly in sera from chronic infections (see Frasch \& Reyes, 1990 for a recent review). Since the sera analyzed were collected from patients in different countries, these results suggest that parasites from different regions express homologous epitopes. In collaboration with $M$. Lorca and U. Vergara (University of Chile) and using synthetic peptides, the presence of antibodies against defined epitopes in sera from human infections was demonstrated. These results raise the possibility of using synthetic peptides in the diagnosis of $T$. cruzi infections (unpublished).

All the genes for parasite antigens we have analyzed are present in $T$. cruzi isolates obtained in Bolivia, Brazil and Argentina (Affranchino et al., 1989; Macina et al., 1989; Macina, 1990; Reyes et al., 1990). Variations in the length of restriction fragments among isolates is mainly due to differences in the number of repeated amino acid units among isolates. As a consequence, homologous antigens might vary in size among parasites as suggested by the results obtained with antigens SAPA and 30. However, main epitopes contained in the 
repeated amino acid units of each antigen seem to be fairly conserved among parasites as judged from the immunological reactivity observed. All together, these results suggest that the antigens under analysis are important for $T$. cruzi.

Lack of detectable variation in the antigens expressed by parasites, and in the immune response, during infection - It has been recently suggested that $T$. cruzi might conserve the basic genetic mechanisms to undergo antigenic variation (Peterson et al., 1989). If this is the case, finding antigens to be used for vaccination might be a difficult task. To know whether antigenic variation might explain that different proteins are antigenic at different periods of infection, antibody specificities present in sera from infected mice were studied and compared with antigens expressed by parasites collected directly from blood (Leguizamón et al., unpublished). Parasites collected during the acute parasitemia peak expressed an antigen from the acute period in human infections (SAPA), but also antigens 1 and 10 , which are characteristic of the chronic period of the infection. However, only antibodies against SAPA were frequently observed during the early period and also in the chronic phase of murine infection. Long lasting antibodies against SAPA were detected regardless of the mouse and parasite strains used. These results indicate that a single parasite is able to express simultaneously those proteins that are antigenic during the acute or chronic phases of human Chagas' disease. Thus we do not find any evidence of variation in these three antigens that might account for differences in the antibody response during acute and chronic phases of the infection. A main conclusion is that the absence of antibodies against the other antigens tested in the murine model is not due to the lack of the corresponding antigens in the parasites. The ability of SAPA to induce antibodies is probably explained by the fact that this antigen is an immunodominant component of the parasite.

The above results were obtained in mice, and they may differ from those in humans. Detection and obtention of parasites from acute human infections is difficult. Consequently, we have at present analyzed the antibodies specificities in longitudinal cases to try to detect any indication of variation in the antibody responses (B. Reyes et al., unpu- blished). Eight recombinant antigens were used to analyze $\operatorname{lgM}$ and $\operatorname{IgG}$ specificities in sera from the follow-up of nine patients who were resistant to chemotherapeutic treatment. All patients had antigen-specific IgMs and IgGs responses that lasted for years. IgG specificities were highly variable among patients in terms of date of appearance and persistance in sera. No indication of a systematic variation in the antibody response in any of these patients was observed.

Protection experiments in the murine experimental model - Recombinant antigens produced in $E$. coli and partially purified by electroelution from preparative polyacrilamide gels were used to obtain monospecific poly. clonal antibodies in rabbits. Immunoglobulins were precipitated with ammonium sulfate and used for passive protection experiments in the murine model (in collaboration with $\mathbf{M}$. A. Basombrio, University of Salta, Argentina). One of the immune sera was able to partially protect mice, to a similar extent as that attained with serum from an infected rabbit. Immunization experiments using the murine model are being conducted in collaboration with $\mathrm{E}$. L. Segura, A. M. Ruiz and M. Esteva, from the Instituto Fatala-Chaben, Buenos Aires. Although the results are still preliminary, one of the recombinant antigens, the same one giving positive results in the experiments of passive transfer of serum, seems to afford partial protection. Although these results are encouraging, further research will be necessary before conclusive evidence can be obtained.

\section{Identification of excreted-secreted parasite} antigens - Exoantigens from some microorganisms are known to be involved in the pathogenesis of the disease. This has also been postulated for parasitic infections like malaria (see Playfair et al., 1990 for a recent review). Thus, it is possible that blocking of exoantigens might result in an anti-disease vaccine. We have recently analyzed the molecules released by $T$. cruzi trypomastigotes that are detected by sera from acute and chronic human infections (E. Jazin et al., unpublished). Sera from acute infections identify two main groups of exoantigens. A first group of proteins with apparent molecular weights ranging from 160 to $200 \mathrm{kDa}$ corresponds to SAPA, the shed acute phase antigen previously identified by our group (Affranchino et al., 1989). A second group of exoantigens detected by four independent 
human acute sera and by sera from acutely infected rabbits has an apparent molecular weight of $40-50 \mathrm{kDa}$. This antigen might be similar to that described recently by Yoshida and co-workers and that might protect against acute infections (Yoshida et al., 1989). A second major exoantigen of $160 \mathrm{kDa}$ was systematically detected by sera from chronic infections. This is in fact, the strongest band detected in supernatants from $T$. cruzi-infected Vero cells with sera from human chronic infections. We have recently cloned a gene enconding this antigen. Its sequence revealed no homology with any of the published genes. It is interesting that an antigen of this size has been reported by Krettli and Brener (Krettli \& Brener, 1982) to be involved in the generation of lytic antibodies and latter confirmed by other groups (Norris et al., 1989). Recently, it was shown that a monoclonal antibody against an $85 \mathrm{kDa}$ excretory-secretory antigen could be used to passively induce a partial protection against infection (Ouaissi et al., 1990). Thus $T$. cruzi exoantigens will probably be an important field of future work in relation with vaccine development.

\section{Inhibition of parasite penetration into host} cells - Since penetration of trypomastigotes into mammalian cells is an essential step for the perpetuation of chagasic infection, inhibition of this process by specific antibodies might result in prevention of the disease. We have recently shown, in collaboration with $\mathrm{W}$. de Souza and T. Souto-Padrón, Universidade Fede. ral do Rio de Janeiro, Brazil, that the F(ab) moiety of antibodies against the major cysteine proteinase, cruzipain, from $T$. cruzi partially blocks parasite penetration into macrophages (Souto-Padrón et al., 1990). This experimental line seems worth pursuing, since we have recently shown that antibodies against cruzipain are present in sera from chronic patients (Martinez et al., unpublished results). Moreover, the complete sequence of cruzipain is now known (Cazzulo, 1991; Aslund et al., unpublished), and it may be possible, therefore, to identify relevant epitopes for the inhibition of parasite internalization.

\section{CONCLUSIONS}

Information gained from the understanding of natural, as well as from experimental, infections, suggest that it might be possible to obtain at least a partial protective immune response. Thus, a vaccine based on a "cocktail" of protective antigens might be obtained and used for the prophylaxis of the disease in endemic areas. Whether diminishing parasite load or complete clearing of parasites during the chronic phase of the infection might result in the prevention of symptomatic disease development (a "curative" vaccine), is still an open question. In any case, there is a long way to go in order to identify the components of this "cocktail" as it is still the case with a malaria vaccine.

\section{ACKNOWLEDGEMENTS}

To all our co-workers at the Fundacion Campomar and L. Aslund, I. Henriksson and U. Pettersson (Uppsala University), E. Segura, A. Ruiz and M. Esteva (Instituto Fatala Chaben). M. Lorca and U. Vergara (University of Chile), A. Luquetti (University of Goiás), M. A. Basombrio (University of Salta) and R. Andersson and A. Orn (Karolinska Institute) for providing us with unpublished results and for helpful discussions.

\section{REFERENCES}

AFFRANCHINO, J. L.; IBAÑEZ, C. F.; LUQUETTI, A. O.; RASSI, A.; REYES, M. B.; MACINA, R. A.; ASLUND, L.; PETTERSON, U. \& FRASCH, A. C. C., 1989. Identification of a Trypanosoma cruzi antigen that is shed during the acute phase of Chagas' discase. Mol. Biochem. Parasitol., 34: 221 228.

ANDREWS, N. W.; ALVES, M. J. M.; SCHUMACHER, R. I. \& COLLI, W. 1985. Trypanosoma cruzi protection in mice immunized with 8-Methoxypsoralen-Inactivated try pomastigotes. Exp. Parasitol., 60: 255-262.

BASOMBRIO, M. A. \& ARREDES, H., 1987. Longterm immunological response induced by attenuated Trypanosoma cruzi in mice. J. Parasitol., 73: 236-238.

BRENER, Z., 1986. Why Vaccines do not work in Chagas disease. Parasitology Today, 2: 196-197.

BURGESS, D. E. \& HANSON, W. L., 1979. Adoptive transfer of protection against Trypanosoma cruzi with lymphocytes and macrophages. Infect. Immun., 25: 838-843.

CAZZULO, J. J., 1991. Cysteine proteinases in Trypanosoma cruzi. G. H. Coombs, \& M. J. North, (eds). Biochemistry of Parasitic Protozoa. Taylor and Francis (In the press).

DE ARRUDA, M. V.; COLLI, W. \& ZINGALES, B., 1989. Terminal $\beta$-D-galactofuranosyl epitopes recognized by antibodies that inhibit Trypanosoma cruzi internalization in to mammalian cells. Eur. $J$. Biochem. 182:413-421.

FRASCH, A. C. C. \& REYES, M. B., 1990. Diagnosis of Chagas Disease using recombinant DNA technology. Parasitol. Today, 6:137-139.

HUDSON, L., 1985. Autoimmune phenomena in 
chronic chagasic cardiopathy. Parasitol. Today, 1 6-9.

IBANEZ, C.; AFIRANCHINO, J. L. \& FRASCH, A C. C., 1987. Antigenic determinants of Trypanosoma cruzi defined by cloning of parasite DNA. Mol. Biochem. Parasitol., 25:175-184.

IBAÑEZ, C. F.; AFFRANCHINO, J. L.; MACINA, R. A.; RFYES, M. B.; LEGUIZAMON, S.; CAMARGO, M. E.; ASLUND, L.; PETTERSSON, U. \& liRASCH, A. C. C., 1988. Multiple Trypanosoma cruzi antigens containing tandemly repeated amino acid sequence motifs. Mol. Biochem. Para. sitol., 30:27-38.

KIERSZENBAUM, F,, 1985. Is there autoimmurity in Chagas disease? Parasitol. Today, 1:4-6.

KIERSZENBAUM, F., 1986. Autoimmunity in Chagas' disease. J. Parasitol., 72: 201-211.

KRETTLI, A. U., 1984. Protective antibodies in Trypanosoma cruzi infections: detection, functional activity and possible mechanisms of trypomastigote killing in vivo and in vitro. Mem. Inst Oswaldo Cruz, 79 (Suppl.):59-65.

KRETTLI, A. U. \& BRENER, Z., 1982. Resistance against Trypanosoma cruzi associated to anti-living trypomastigote antibodies. J. Immunol, 128: 2009-2012.

LIMA-MARTINS, M. V. C.; SANCHEZ, G. A.; KRETTLI, A. U. \& BRENER, Z, 1985. Antibodydependent cell cytotoxicity against Trypanosoma cruzi is only mediated by protective antibodies. Parasit. Immunol. 7: 367-376.

MACINA, R. A., 1990. Diversidad de secuencia de los minicirculos del Trypanosoma cruzi. Ph. D. Thesis, University of Buenos Aires.

MACINA, R. A.; AFFRANCHINO, J. L.; POLLEVICK, G. D.; JAZIN, E. E. \& FRASCH, A. C. C., 1989. Variable number of repeat units in genes encoding Trypanosoma cruzi antigens. FEBS Lett. 257: 365-368.

MORTARA, R. A.; ARAGUTH, M. F. \& YOSHIDA, N., 1988. Reactivity of stage-specific monoclonal antibody 1G7 with metacyclic trypomastigotes of Trypanosoma cruzi strains: lytic property and $90,000 \mathrm{~mol}$. wt surface antigen polymorphysm. Parasite Immunol, 10:369-378.

NICKELL, S. P. \& BOYER, M. H., 1986. Trypanosoma cruzi protective immunization of susceptible strains of mice prone to autoimmunity. Exp. Parasitol., 62:450-452.

NORRIS, K. A.; HARTH, G. \& SO, M., 1989. Purification of a Trypanosoma cruzi membrane glycoprotein wich elicits lytic antibodies. Infect. Immun., 57: 2372-2377.

OKANLA, E. O.; STUMPF, J. L. \& DUSANIC, D. G., 1982. Resistance of mice immunized with irradiated and lyophilized stages of Trypanosome cruzi to infections with metacyclics. Int. J. Parasitol, 12: 251-256.

OUAISSI, M. A.; TAlBl, A.; CORNETTE, J .; VELGE, P.; MARTY, B.; LOYENS, M.; ESTEVA, M.; RIZVI, F. S. \& CAPRON, A., 1990. Characterization of major surface and excretory-secretory immunogens of Trypanosoma cruzi trypomastigotes and identification of potential protective antigen. Parasitology, 100:115-124.

PETERSON, D. S.; FOUTS, D L. \& MANNING, J. E., 1989. The 85-Kd surface antigen gene of Trypanosoma cruzi is telomeric and a member of a multigene family. EMBO J., 8:3911-3916.

PETRY, K. \& EISEN, H., 1989. Chagas disease: a model for the study of autoimmune diseases. Parasitol. Today, 5:111-116.

PLAYFAIR, J. H. L.; TAVERNE, J.; BATE, C. A. W. \& DE SOUZA, J. B., 1990. The malaria vaccine anti-parasite or anti-disease? Immunol. Today, 11: $25 \cdot 27$

REYES, M. B.; LORCA, M.; MUÑOZ, P.\& FRASCH, A. C. C. 1990. Fetal IgG specificities against Trypanosoma cruzi antigens in infected newborns. Proc. Natl. A cad. Sci. USA, 87: 2846-2850.

RITTER, D. M. \& ROWLAND, E. C., 1984. Corpus christi strain-induced protection to Trypanosoma cruzi infection in $\mathrm{C} 3 \mathrm{H}(\mathrm{He})$ mice: effective dose, time, route, and number of vaccinations. $J$. Parasit., 70:755-759.

RUIZ, A. M.; ESTEVA, M.; CABEZA MECKERT, P.; LAGUENS, R. P.\& SEGURA, E. L., 1985. Protective immunity and pathology induced by inoculation of mice with different subcellular fractions of Trypanosoma cruzi. Acta Trop. 42:299-309.

RUIZ, A. M.; ESTEVA, M.; SUBIAS, E.; MORENO, M.; CAMPANINI, A. R. D.; VELAZQUEZ, E. \& SEGURA, E. L., 1990. Monoclonal antibodies against the flagellar fraction of epimastigotes of Trypanosoma cruzi immunoprotection against metacyclic trypomastigotes obtained by immunization of mice with an affinity-purified antigen. Mol. Biochem. Parasitol., 39: 117-126.

SCOTT, M. T., 1981. The nature of immunity against Trypanosoma cruzi in mice recovered from acute infection. Parasit. Immunol., 3: 209-218.

SCOTT, M. T.; BAHR, G.; MODDABER, F.; AFCHAIN, D. \& CHEDID, L., 1984. Adjuvant requirements for protective immunization of mice using a Trypanosoma cruzi $90 \mathrm{~K}$ cell surface glycoprotein. Int. Archs Allergy Appl. Immun., 74: 373-377.

SCOTT, M. T.; NEAL, R. A. \& WOODS, N. C., 1985. Immunization of marmosets with Trypanosome cruzi cell surface glycoprotein (GP90). Trans. $R$. Soc. Trp. Med. Hyg., 79:451-454.

SCOTT, M. T. \& SNARY, D., 1979. Protective immunization of mice using cell surface glycoprotein from Trypanosoma cruzi. Nature, 282:73-74

SNARY, D., 1983. Cell surface glycoproteins of Trypanosoma cruzi protective immunity in mice and antibody levels in human chagasic sera. Trans. $R$. Soc. Trop. Med. Hyg., 77: 126-129.

SOUTO-PADRON, T.; CAMPETELLA, O. E.; CAZZULO, J. J. \& DE SOUZA, W., 1990. Cysteineproteinase in Trypanosoma cruzi: immunocytochemical localyzation and involvement in parasitehost cell interaction. J. Cell Sci., 96: 485-490.

SOUTO-PADRON, .T.; REYES, M. B.; LEGUIZAMON, S.; CAMPETELLA, O. E.; FRASCH, A. C. C. \& DE SOUZA, W. 1989. Trypanosoma cruzi proteins wich are antigenic during human infections are located in defined regions of the parasite. Eur. J. Cell Biol., 50: 272-278.

TIBAYRENC, M. \& AYALA, F. J., 1987. Trypanosoma cruzi populations: more clonal than sexual. Parasitol. Today, 3: 189-190.

TRISCHMANN, T. M., 1984. Role of cellular immunity in protection against Trypanosoma cruzi in mice. Parasite Im munol., 6:561-570. 
VILLALTA, F， \& KIERSZENBAUM, F., 1983. Immunization against a challenge with insect vector, metacyclic forms of Trypanosoma cruzi simulating a natural infection. Am. J. Trop. Med. Hyg., 32: 273-276.

YOSHIDA, N.; MORTARA, R. A.; ARAGUTH, M. F.; GONZALEZ, J. \& RUSSO, M., 1989. Metacyclic neutralizing effect of monoclonal antibody 10D8 directed to the 35- and 50-Kilodaltons surface glycoconjugates of Trypanosoma cruzi. Infect. Immun., 57: 1663-1667.
ZINGALES, B.; ANDREWS, N. W.; KUWAJIMA, V. Y. \& COLLI, W., 1982. Cell surface antigens of Trypanosoma cruzi. Possible correlation with the interiorization process in mammalian cells. Mol. Biochem. Parasitol., 6:111-124.

ZWEERINK, H. J.; WESTON, H. D.; ANDERSEN, O. F.; GARBER, S. S. \& HAYES, E. C., 1984. Immunity against infection with Trypanosoma cruzi in mice correlates with presence of antibodies against three trypomastigote polypeptides. Infect. Immun., 46: 826-830. 